\title{
Morphometric investigations in mitral stenosis using two dimensional echocardiography
}

\author{
PETER SCHWEIZER, PETER BARDOS, WINFRIED KREBS, RAIMUND ERBEL, CARMINE \\ MINALE, STEPHAN IMM, BRUNO JOSEF MESSMER, SVEN EFFERT
}

From the Department of Internal Medicine I and Department of Cardiovascular Surgery, Rheinisch-Westfälische Technische Hochschule, Aachen, West Germany

SUMMARY A method is proposed for comparing the orifice size and the morphology of stenotic mitral valves, removed intact at the time of replacement, with the preoperative two dimensional echocardiographic cross-sections. The excised mitral valve apparatus is suspended on a specially constructed mounting. To avoid shrinkage the orifice is stabilised with an airfilled balloon. A radiograph is taken directing the $x$-ray beam perpendicular to the valve orifice.

In 40 of 51 patients this method provided the means of relating the echocardiographic crosssections to the morphology of the valve. Planimetry of the valve area compared favourably with the postoperatively determined orifice size. Agreement was found in 34 of 40 patients in orifice shape between preoperative echocardiograms and $x$-rays of the excised valve. The relation between intraoperative estimation of size of the valve, using dilators with known diameters, and the postoperative results was less favourable.

Areas of calcification were identified on echocardiography as dense conglomerate echoes. In 30 patients (75\%) the localisation of calcium deposits and in $67 \%$ the degree of calcification was in agreement with the $x$-rays of the valve taken after operation.

In addition to determination of the area, two dimensional echocardiography allows detailed studies of the stenotic valves, and is of particular importance for planning operative treatment.

The limitations of M-mode echocardiography in predicting the severity of mitral valve stenosis are well known. ${ }^{12}$ In contrast, with two dimensional echocardiography in short axis planes it is possible to image the total circumference of the stenosed valve orifice. The valve area can then be calculated by means of planimetry. ${ }^{3}$ Several studies have correlated those measurements with the Gorlin-derived valve area. ${ }^{4-6}$

In addition, Henry et al. ${ }^{3}$ found a close correlation between cross-sectional echocardiography and intraoperative measurement. In 13 of 14 patients with mitral valve disease the orifice area measured from two dimensional images was within $0.3 \mathrm{~cm}^{2}$ of the orifice area measured directly at operation. But in these investigations the morphology of the mitral valve apparatus, obtained by both methods, had not been analysed in detail.

The purpose of this study was to assess the role of cross-sectional echocardiography in predicting the area and shape of the orifice as well as the grade and

Accepted for publication 10 December 1981 distribution of valve calcifications. Therefore a special method for morphometric analysis of stenosed valves removed during operation was proposed.

\section{Subjects and methods}

The study group consisted of 51 consecutive patients undergoing operation for mitral valve disease. There were 35 women and 16 men whose ages ranged from 36 to 69 years, mean 52 years.

Cardiac catheterisation was performed in each patient: 18 had pure mitral stenosis, and 33 had clinical and angiographic evidence of associated mild to moderate mitral regurgitation.

\section{ECHOCARDIOGRAPHIC METHODS}

All ultrasonic examinations were carried out using a commercially available phased array $80^{\circ}$ sector scanner (Varian V3000, Varian Ass. Palo Alto, USA). This instrument has been previously described in detail. ${ }^{7}$ The two dimensional echocardiographic 54 
to that described by Henry et al. ${ }^{3}$ The transducer was placed in the left parasternal region, usually in the third, fourth, or fifth intercostal space. The sector scan image was initially orientated parallel to the long axis of the left ventricle in order to visualise the anterior and posterior mitral leaflets with their chordal and papillary muscle attachments. The transducer was then rotated $90^{\circ}$ clockwise to obtain a short axis view of the left ventricle. From the transducer position a sweep was performed by slowly angling the image plane from the aorta to the apex. Thus the stenotic mitral valve orifice, forming the apex of the mitral valve funnel, could be directly imaged. Care was taken to adjust the instrument to an optimal level so that continuous echoes around the circumference of the orifice could be recorded.

The cross-sectional images were recorded on a $1 / 2$ inch videotape system for later playback and review (Sanyo VTC 3000, Sanyo USA). The illustrations presented in this article are $35 \mathrm{~mm}$ photographs of single frame images from the videotape.

\section{INTRA- AND POSTOPERATIVE ASSESSMENT}

During operation an estimate of the dimensions of the mitral valve orifice was made using Hegar dilators with known diameters. The circle area $\left(\pi r^{2}\right)$ was calculated.

In patients where valve replacement was thought to be necessary the intact mitral valve including the chordae and the tips of the papillary muscles was excised. The valve was carefully examined by palpation and was subsequently suspended on a specially constructed holding. To avoid shrinkage the orifice was stabilised with an airfilled balloon of known pressure. The balloon pressure was individually adjusted to the rigidity of the valve and did not exceed 25 $\mathrm{mmHg}$. Then a radiograph was taken, directing the $x$-ray beam perpendicular to the mitral valve orifice. A radio-opaque scale was simultaneously filmed for later quantification (Fig. 1).

Thus, the shape and the area of the orifice and the amount of calcium around the circumference could be judged by a technique similar to cross-sectional echocardiography.

\section{DATA ANALYSIS}

The two dimensional echocardiograms were interpreted in a double-blind fashion and without knowledge of the later radiographic findings of the excised mitral valve.

The orifice area was planimetered during early diastole using a commercially available image analyser (Echo-comp, Digisonics Inc., Houston, USA). The location of the calcium deposits was identified and their amount was graded by previously described morphological criteria; that is, the extent was deter-

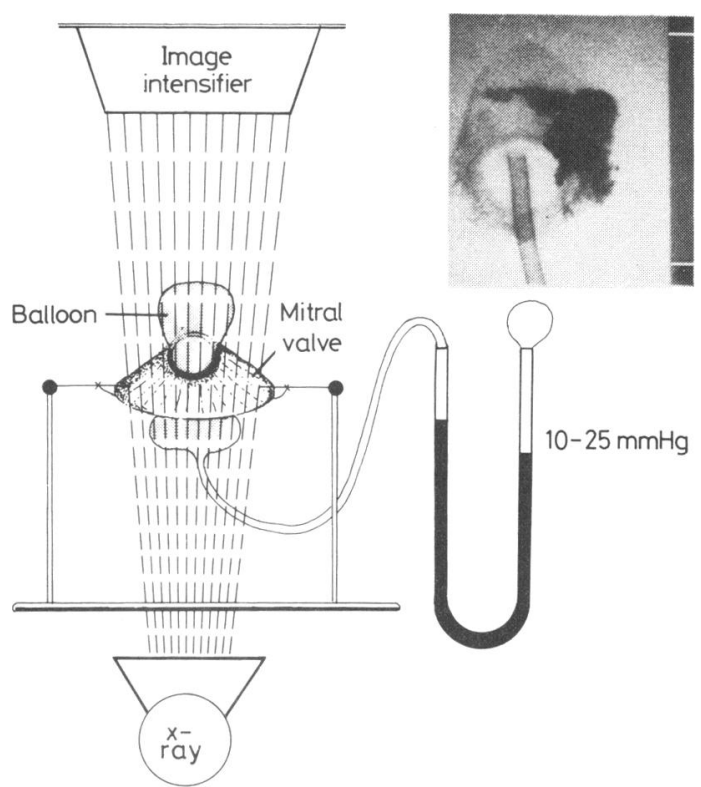

Fig. 1 Proposed method for morphometric analysis (schematic drawing). The stenotic mitral valve removed intact during operation is placed on a specially constructed mounting. The orifice is stabilised with an airfilled balloon of known pressure. Then a radiograph is taken, directing the $\mathrm{x}$-ray beam perpendicular to the mitral valve orifice. Upper right part: excised mitral valve including a scale after $\mathrm{x}$-ray exposure. The mitral valve orifice as well as the calcifications are clearly visualised.

mined by the percentage of the valvular circumference containing the deposits (grade $0=$ no calcification, grade $1=<25 \%$, grade $2=25$ to $50 \%$, grade $3=51$ to $75 \%$, grade $4=>75 \%$ ). ${ }^{8}$

Statistical analysis of the mitral valve area was performed with the paired Student's $t$ test. The correct correspondence in orifice shape and in the localisation of calcification was judged at the end of the study by the two independent investigators.

\section{Results}

The results of the correlative two dimensional echocardiographic and postoperative evaluation are summarised in the Table. Five of 51 patients were excluded from the study because of technically inadequate echocardiographic recording. In six further patients no pathological specimen was available because either open commissurotomy was performed or the valve had to be cut into pieces at the time of excision.

VALVE ORIFICE AREA

Fig. 2 shows the relation between the mitral valve 
Schweizer, Bardos, Krebs, Erbel, Minale, Imm, Messmer, Effert

Table Data obtained from 40 patients with mitral stenosis using two dimensional echocardiography and direct measurement of valve

\begin{tabular}{|c|c|c|c|c|c|c|c|c|c|}
\hline \multirow{2}{*}{$\begin{array}{l}\text { Case } \\
\text { No. }\end{array}$} & \multirow[t]{2}{*}{ Sex } & \multirow{2}{*}{$\begin{array}{l}\text { Age } \\
(y)\end{array}$} & \multicolumn{3}{|c|}{ Mitral valve area } & \multirow{2}{*}{$\begin{array}{l}\text { Localisation of } \\
\text { calcium- } 2 D E\end{array}$} & \multirow{2}{*}{$\begin{array}{l}\text { Localisation of } \\
\text { calcium-po }\end{array}$} & \multirow{2}{*}{$\begin{array}{l}\text { \%/degree of } \\
\text { calcification- } 2 D E\end{array}$} & \multirow{2}{*}{$\begin{array}{l}\text { \%/degree of } \\
\text { calcification-po }\end{array}$} \\
\hline & & & $\begin{array}{l}\text { Area-2DE } \\
\left(\mathrm{cm}^{2}\right)\end{array}$ & $\begin{array}{l}\text { Area-po } \\
\left(\mathrm{cm}^{2}\right)\end{array}$ & $\begin{array}{l}\text { Area-io } \\
\left(\mathrm{cm}^{2}\right)\end{array}$ & & & & \\
\hline $\begin{array}{l}1 \\
2 \\
3 \\
4 \\
5 \\
6\end{array}$ & $\begin{array}{l}\mathbf{F} \\
\mathbf{F} \\
\mathbf{M} \\
\mathbf{M} \\
\mathbf{M} \\
\mathbf{F}\end{array}$ & $\begin{array}{l}65 \\
60 \\
59 \\
52 \\
57 \\
58\end{array}$ & $\begin{array}{l}1.3 \\
1.45 \\
3.7 \\
1.6 \\
1.8 \\
1.6\end{array}$ & $\begin{array}{l}1.4 \\
1.4 \\
3.0 \\
1.8 \\
1.7 \\
1.3\end{array}$ & $\begin{array}{l}\overline{1 \cdot 35} \\
\overline{-} \\
\frac{2 \cdot 3}{-}\end{array}$ & $\begin{array}{l}\text { AL, PL } \\
\text { AL, MC } \\
\text { PL } \\
\text { AL, MC } \\
\text { PL, LC } \\
\text { AL, PL, MC, } \\
\quad \text { LC }\end{array}$ & $\begin{array}{l}\text { AL, PL } \\
\text { AL } \\
\text { PL } \\
\text { AL, MC } \\
\text { AL, LC } \\
\text { AL, PL, MC, LC }\end{array}$ & $\begin{array}{l}80 \% \text { grade } 4 \\
60 \% \text { grade } 3 \\
10 \% \text { grade } 1 \\
20 \% \text { grade } 1 \\
25 \% \text { grade } 1 \\
90 \% \text { grade } 4\end{array}$ & $\begin{array}{r}80 \% \text { grade } 4 \\
70 \% \text { grade } 3 \\
5 \% \text { grade } 1 \\
25 \% \text { grade } 1 \\
25 \% \text { grade } 1 \\
90 \% \text { grade } 4\end{array}$ \\
\hline $\begin{array}{r}7 \\
8 \\
9 \\
10 \\
11 \\
12 \\
13 \\
14 \\
15 \\
16\end{array}$ & $\begin{array}{l}\mathbf{F} \\
\mathbf{M} \\
\mathbf{F} \\
\mathbf{M} \\
\mathbf{M} \\
\mathbf{F} \\
\mathbf{M} \\
\mathbf{F} \\
\mathbf{F} \\
\mathbf{F}\end{array}$ & $\begin{array}{l}61 \\
55 \\
55 \\
56 \\
57 \\
59 \\
60 \\
60 \\
58 \\
59\end{array}$ & $\begin{array}{l}2.35 \\
1.7 \\
1.45 \\
2.05 \\
1.6 \\
1.55 \\
2.25 \\
1.75 \\
1.3 \\
2.6\end{array}$ & $\begin{array}{l}2.1 \\
1.8 \\
1.4 \\
1.85 \\
1.6 \\
1.85 \\
3.1 \\
1.55 \\
1.4 \\
2.65\end{array}$ & $\begin{array}{l}\overline{2} \\
1 \cdot 3 \\
2.25 \\
1.35 \\
2.25 \\
\overline{1.75} \\
=\end{array}$ & $\begin{array}{l}\text { AL, LC } \\
\text { AL, LC } \\
\text { PL, MC } \\
\text { AL, PL } \\
\text { AL, MC } \\
\text { AL, LC } \\
\text { PL, MC } \\
\text { PL } \\
\text { PL } \\
\text { AL, PL, MC, } \\
\quad \text { LC }\end{array}$ & $\begin{array}{l}\text { AL, LC } \\
\text { AL } \\
\text { PL, MC } \\
\text { PL, LC, MC } \\
\text { AL, MC } \\
\text { AL, LC } \\
\text { PL, MC } \\
\text { LC } \\
\text { AL, PL } \\
\text { AL, PL, MC, LC }\end{array}$ & $\begin{array}{l}60 \% \text { grade } 3 \\
80 \% \text { grade } 4 \\
25 \% \text { grade } 1 \\
60 \% \text { grade } 3 \\
40 \% \text { grade } 2 \\
40 \% \text { grade } 2 \\
30 \% \text { grade } 2 \\
30 \% \text { grade } 2 \\
30 \% \text { grade } 2 \\
80 \% \text { grade } 4\end{array}$ & $\begin{array}{l}60 \% \text { grade } 3 \\
60 \% \text { grade } 3 \\
35 \% \text { grade } 2 \\
60 \% \text { grade } 3 \\
50 \% \text { grade } 2 \\
20 \% \text { grade } 1 \\
40 \% \text { grade } 2 \\
25 \% \text { grade } 1 \\
50 \% \text { grade } 2 \\
80 \% \text { grade } 4\end{array}$ \\
\hline $\begin{array}{l}17 \\
18 \\
19 \\
20 \\
21 \\
22 \\
23 \\
24 \\
25 \\
26 \\
27 \\
28 \\
29 \\
30 \\
31 \\
32 \\
33\end{array}$ & $\begin{array}{l}F \\
F \\
F \\
M \\
F \\
F \\
M \\
F \\
F \\
F \\
F \\
F \\
F \\
F \\
F \\
F \\
F\end{array}$ & $\begin{array}{l}52 \\
63 \\
36 \\
57 \\
45 \\
39 \\
44 \\
41 \\
45 \\
45 \\
54 \\
49 \\
46 \\
49 \\
58 \\
53 \\
52\end{array}$ & $\begin{array}{l}2.8 \\
1.85 \\
1.25 \\
2.75 \\
1.2 \\
2.25 \\
1.7 \\
1.5 \\
1.25 \\
1.0 \\
1.5 \\
1.5 \\
1.5 \\
1.35 \\
2.8 \\
2.2 \\
0.8\end{array}$ & $\begin{array}{l}2.9 \\
2.0 \\
1.0 \\
2.6 \\
1.25 \\
2.2 \\
1.85 \\
0.95 \\
1.0 \\
1.3 \\
1.35 \\
1.35 \\
1.4 \\
1.4 \\
2.9 \\
2.25 \\
0.75\end{array}$ & $\begin{array}{l}\overline{1} \\
\overline{-} \\
\overline{1} .15 \\
2.85 \\
2.25 \\
0.95 \\
2.0 \\
1.35 \\
1.35 \\
2.25 \\
\frac{2.0}{-} \\
=\end{array}$ & $\begin{array}{l}\text { AL } \\
\text { AL, MC } \\
\text { MC } \\
\text { PL, MC, LC } \\
\text { PL } \\
\text { AL, MC } \\
\text { PL, MC } \\
\text { AL } \\
\text { MC, LC } \\
\text { AL } \\
\text { AL } \\
\text { AL, MC, LC } \\
\text { AL } \\
\text { AL, MC } \\
\text { AL, PL } \\
\text { AL, LC } \\
\text { AL, PL, MC, }\end{array}$ & $\begin{array}{l}\mathrm{AL} \\
\mathrm{AL}, \mathrm{MC} \\
\mathrm{MC} \\
\mathrm{MC}, \mathrm{LC} \\
\mathrm{PL} \\
\mathrm{AL}, \mathrm{MC} \\
\mathrm{PL}, \mathrm{MC}, \mathrm{LC} \\
\mathrm{AL} \\
\mathrm{MC}, \mathrm{LC} \\
\overline{\mathrm{AL}} \\
\mathrm{AL}, \mathrm{MC}, \mathrm{LC} \\
\mathrm{AL} \\
\mathrm{AL} \\
\mathrm{AL}, \mathrm{PL} \\
\mathrm{AL}, \mathrm{LC} \\
\mathrm{AL}, \mathrm{PL}, \mathrm{MC},\end{array}$ & $\begin{array}{l}70 \% \text { grade } 3 \\
45 \% \text { grade } 2 \\
20 \% \text { grade } 1 \\
50 \% \text { grade } 2 \\
10 \% \text { grade } 1 \\
30 \% \text { grade } 2 \\
70 \% \text { grade } 3 \\
20 \% \text { grade } 1 \\
30 \% \text { grade } 2 \\
20 \% \text { grade } 1 \\
55 \% \text { grade } 3 \\
25 \% \text { grade } 2 \\
40 \% \text { grade } 2 \\
55 \% \text { grade 3 } \\
80 \% \text { grade } 4 \\
60 \% \text { grade 3 } \\
100 \% \text { grade } 4\end{array}$ & $\begin{array}{r}70 \% \text { grade } 3 \\
45 \% \text { grade } 2 \\
20 \% \text { grade 1 } \\
20 \% \text { grade 1 } \\
10 \% \text { grade 1 } \\
30 \% \text { grade 2 } \\
40 \% \text { grade 2 } \\
20 \% \text { grade 1 } \\
30 \% \text { grade 2 } \\
0 \% \text { grade 0 } \\
55 \% \text { grade 3 } \\
50 \% \text { grade 2 } \\
20 \% \text { grade 1 } \\
20 \% \text { grade 1 } \\
60 \% \text { grade 3 } \\
50 \% \text { grade 2 } \\
100 \% \text { grade 4 }\end{array}$ \\
\hline $\begin{array}{l}34 \\
35 \\
36\end{array}$ & $\begin{array}{l}\mathbf{F} \\
\mathbf{M}\end{array}$ & $\begin{array}{l}57 \\
44 \\
50\end{array}$ & $\begin{array}{l}2.45 \\
1.5 \\
1.5\end{array}$ & $\begin{array}{l}2.8 \\
1 \cdot 4 \\
1.4\end{array}$ & $\bar{z}$ & $\begin{array}{l}\text { PL } \\
\text { AL, PL, LC } \\
\text { AL, PL, MC, } \\
\quad \text { LC }\end{array}$ & $\begin{array}{l}\text { PL } \\
\text { AL, PL, LC } \\
\text { AL, PL, MC, LC }\end{array}$ & $\begin{array}{l}40 \% \text { grade } 2 \\
70 \% \text { grade } 3 \\
80 \% \text { grade } 4\end{array}$ & $\begin{array}{l}40 \% \text { grade } 2 \\
70 \% \text { grade } 3 \\
80 \% \text { grade } 4\end{array}$ \\
\hline $\begin{array}{l}37 \\
38 \\
39 \\
40\end{array}$ & $\begin{array}{l}\mathbf{F} \\
\mathbf{F} \\
\mathbf{M}\end{array}$ & $\begin{array}{l}41 \\
69 \\
56 \\
52\end{array}$ & $\begin{array}{l}1.45 \\
0.6 \\
1.4 \\
1.55\end{array}$ & $\begin{array}{l}1.4 \\
0.6 \\
1.4 \\
1.25\end{array}$ & $\begin{array}{l}\bar{Z} \\
\overline{1.55}\end{array}$ & $\begin{array}{l}\text { LC } \\
\text { AL } \\
\text { LC } \\
\text { AL, LC }\end{array}$ & $\begin{array}{l}\text { LC } \\
\text { AL } \\
\text { LC } \\
\text { AL, LC }\end{array}$ & $\begin{array}{l}60 \% \text { grade } 3 \\
50 \% \text { grade } 2 \\
60 \% \text { grade } 3 \\
70 \% \text { grade } 3\end{array}$ & $\begin{array}{l}60 \% \text { grade } 3 \\
50 \% \text { grade } 2 \\
60 \% \text { grade } 3 \\
70 \% \text { grade } 3\end{array}$ \\
\hline
\end{tabular}

Abbreviations: Area-2DE, -po, -io, mitral valve area, obtained with two dimensional echocardiography, postoperatively, intraoperatively; AL, PL, anterior, posterior leaflet; MC, LC, medial, lateral commissure.

orifice area measured by two dimensional echocardiography and the mitral valve area measured postoperatively in $\mathbf{4 0}$ patients. The valve areas derived from two dimensional short axis views were between 0.62 and $3.7 \mathrm{~cm}^{2}$, the mean value being $1.74 \pm 0.61$ $\mathrm{cm}^{2}$. The correlation coefficient between these values and the areas obtained postoperatively was extremely good $(r=0.92)$. The standard error of estimate was below $0.3 \mathrm{~cm}^{2}$ and the maximum difference between the echo and postmortem estimates in any pair of estimates was $0.85 \mathrm{~cm}^{2}$.

In 19 of 40 patients intraoperative estimates of size of the mitral valve using Hegar dilators with known diameters was also performed. The relation between these measurements and the planimetered orifice areas of the excised mitral valves is depicted in Fig. 3.
The correlation coefficient was 0.63 and the standard error of estimate (SEE) was $0.42 \mathrm{~cm}^{2}$. The relation between the areas determined by two dimensional echocardiography and the values obtained during operation was in the same range, the correlation coefficient being $0.58\left(\mathrm{SEE}=0.44 \mathrm{~cm}^{2}\right)$.

\section{VALVE ORIFICE SHAPE: LOCALISATION OF CALCIFICATION}

The shape of the stenosed mitral orifice, which was analysed in 40 patients, was not uniform but often showed bizarre configurations. Representative examples obtained by both methods are shown in Fig. 4 .

A precise agreement in orifice shape between preoperative two dimensional echocardiograms and $x$-rays of the excised mitral valve was found in 34 


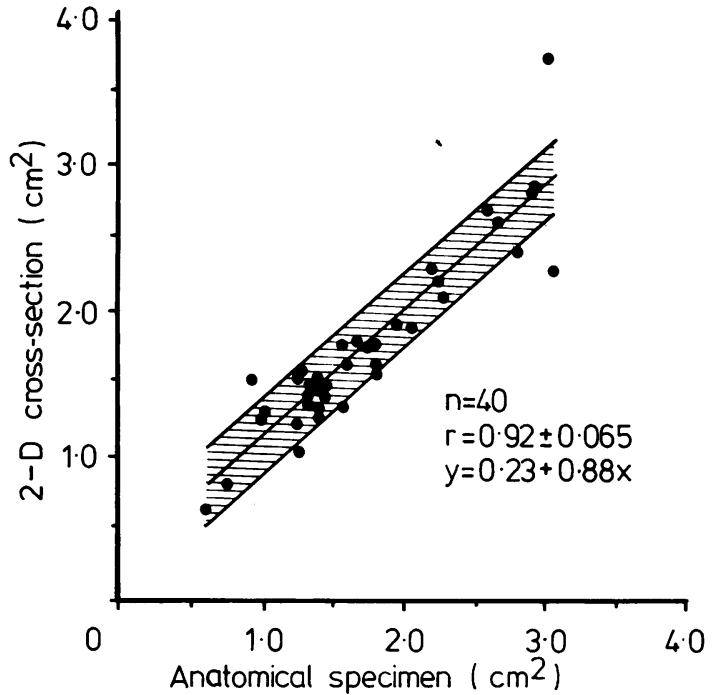

Fig. 2 Display of the data obtained from 40 patients correlating the mitral valve areas calculated with two dimensional echocardiography with $\mathrm{x}$-ray exposure of the anatomical specimen. (SEE is within the shaded area.)

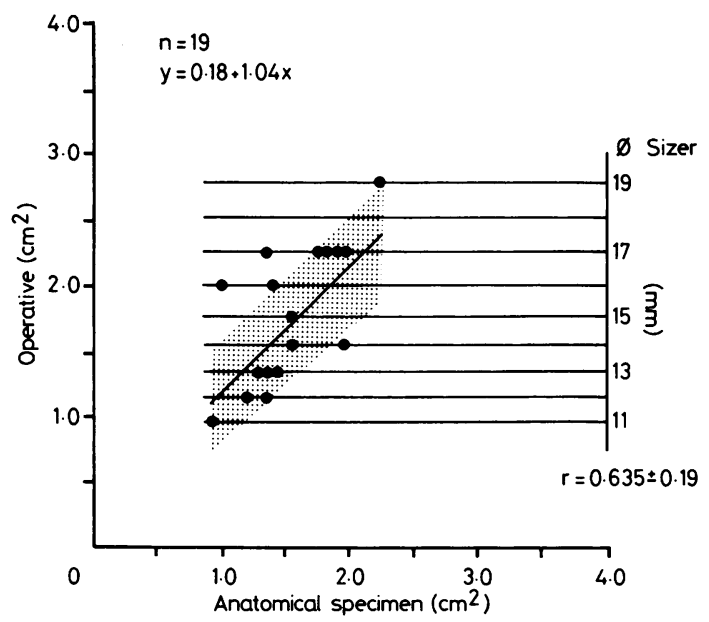

Fig. 3 Relation between the areas obtained during operation using a sizer of known diameter and the $\mathrm{x}$-ray picture of the excised mitral valve. (SEE is within the shaded area.)
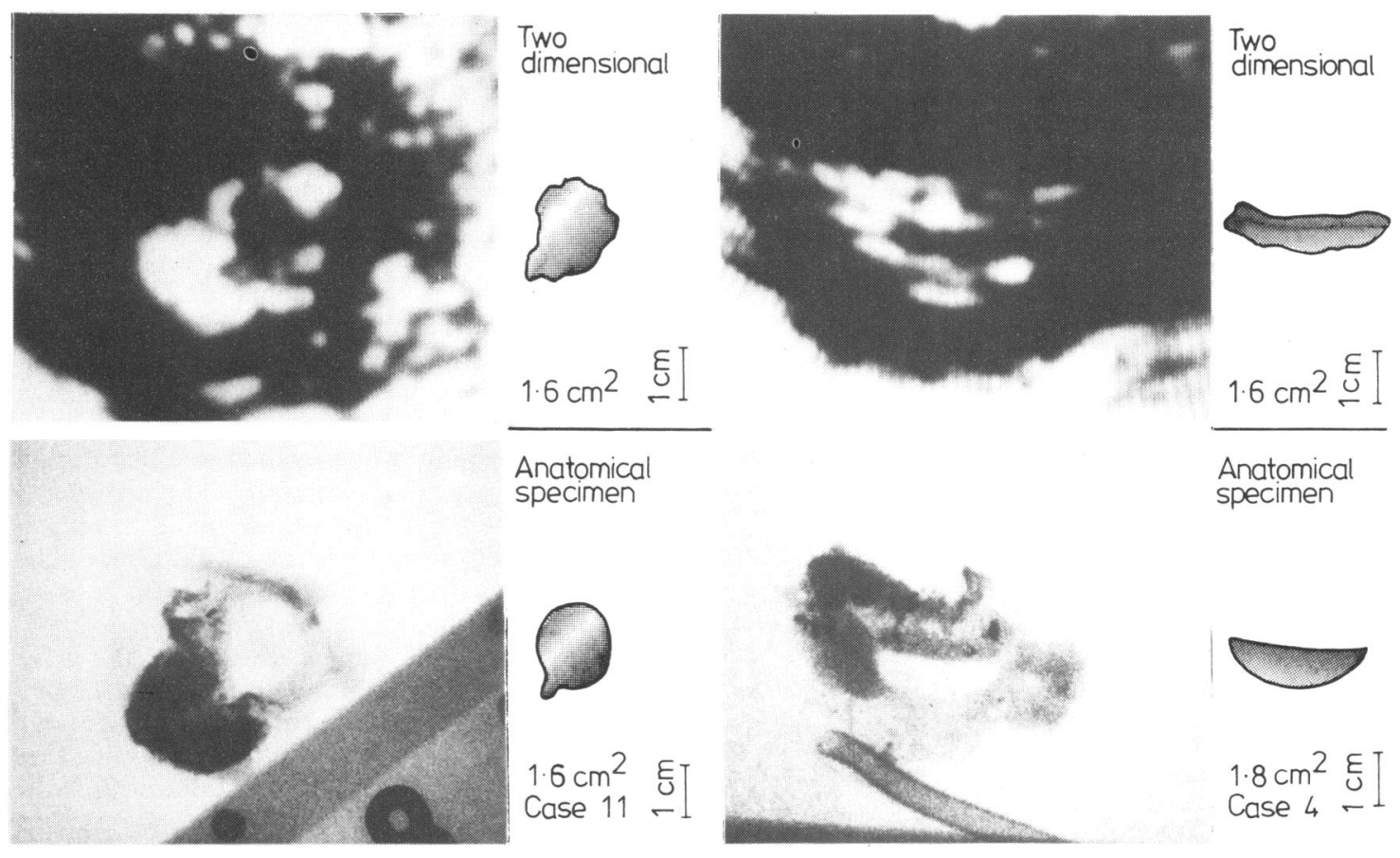

Fig. 4 Examples of preoperative short axis views of the stenotic mitral valve (above) and of corresponding $\mathrm{x}$-rays of the valve after replacement (below), showing good agreement in shape and calcium localisation. $-=1 \mathrm{~cm}$. 


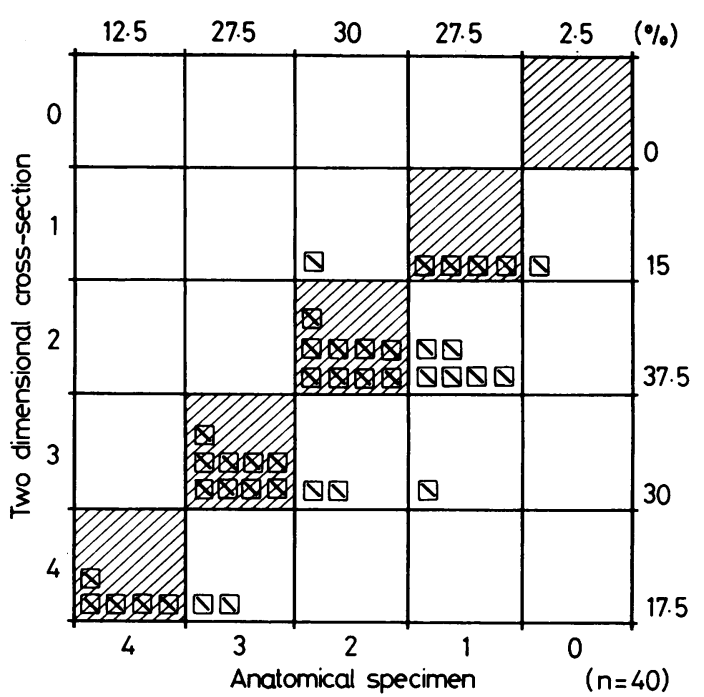

Fig. 5 Graph showing the correlation of the degree of valve calcification determined with two dimensional echocardiography with $x \rightarrow$ ay exposure of the anatomical specimen. A grading system 0-4 was used (see text). The shaded areas indicate agreement with both methods. The amount of calcific deposits was partly overestimated by two dimensional echocardiography (clear fields to the right).

patients (85\%). In the remaining six patients the two independent investigators judged the echocardiographic findings as incorrect.

Areas of calcification were echocardiographically identified as dense conglomerate echoes and were broadly evident in all 40 patients. Calcification could be morphologically confirmed in 39 of 40 patients. The echocardiogram showed the exact localisation of these calcium deposits on the anterior and posterior mitral leaflet, and on the medial and lateral commissure in 30 patients ( $75 \%$ ) (Table).

\section{DEGREE OF CALCIFICATION}

Thirty-nine excised mitral valves showed some degree of calcification (Table). With application of the proposed system (grade 0 to 4 ) agreement with both methods was found in 27 of 40 patients (67\%). With this classification the degree of calcification was overestimated with two dimensional echocardiography in 12 patients (Fig. 5). But this overestimation was not statistically significant. In only 10 patients $(25 \%)$ was the difference in severity of calcification using the two methods more than $10 \%$ (Table).

\section{Discussion}

By providing correct spatial orientation crosssectional echocardiography allows an appropriate characterisation of the mitral valve. Several studies suggest that a reliable non-invasive estimation of the severity of valve stenosis is now possible. Taking valve orifice area from the two dimensional echocardiogram, a good correlation was shown between both intraoperative estimations of size of the orifice and the mitral valve area calculated by the Gorlin formula. ${ }^{3-69}$

Using a different approach, we came to similar conclusions with respect to mitral valve orifice area. Our proposed method of preparing and imaging the stenotic valve postoperatively provided the means of relating the two dimensional echocardiographic findings to the morphology of the valve. A true radiographic visualisation of the mitral valve orifice itself was possible, as with two dimensional cross-section. This method was, therefore, independent of catheterisation data and of the presence or absence of additional mitral regurgitation.

The correlation in our study was good, the correlation coefficient being 0.92 with 40 patients. These results confirm preliminary studies of Wann et al. ${ }^{5}$ who measured the valve area in some pathological specimens and also found good accuracy of two dimensional echocardiography. To prevent shrinkage of the orifice, in this study the pathological specimen was fixed to its main diastolic position immediately after operation.

The discrepancies between area measurements with both methods (range 0 to $0.85 \mathrm{~cm}^{2}$ in our study) are caused by technical limitations of the ultrasound method. One limiting factor, the varying orifice size resulting from different gain settings, has been systematically investigated and was carefully taken into account in this study. ${ }^{10}$ Another critical point is the proper location of the transducer directly over the mitral valve orifice to avoid sloping sections of the orifice and therefore overestimation. ${ }^{1011}$ This factor is probably responsible for some differences between single values of the area obtained with two dimensional echocardiography in relation to the pathology of the valve.

Another limitation of the method was that during $x$-ray exposure of the excised mitral valve an airfilled balloon was inserted to avoid shrinkage of the orifice, which may lead to an overextension of the orifice. The data, however, do not confirm this difficulty because with two dimensional echocardiography there is overestimation rather than underestimation of the valve area. It is unlikely that a rigid stenotic mitral valve orifice reacts much to low pressure balloon extension.

The good correlation between the mitral valve area shown on cross-sectional scanning and the orifice area derived from pathological specimens contrasts, to some extent, with the intraoperative measurements. Whereas Henry et al. ${ }^{3}$ found an excellent correlation between echocardiography and intraoperative estima- 
tion of size, our correlation coefficient was only 0.53 .

One explanation for these discrepancies is that in our study no custom-built estimator of size was used for the area measurements. The orifice area was instead derived from the largest diameter of the orifice obtained during the operation. One further possible reason is that in our investigation the valve circumference mostly showed a bizarre configuration, unsuitable even for a specially preformed estimator of size.

Other investigators also emphasise the methodological difficulties inherent in the intraoperative estimation of size of stenosed mitral valves.45 Wann et al. ${ }^{5}$ for example had been unable to develop a satisfactory method for measuring the mitral valve area during operation for comparison with two dimensional echocardiography.

The structural architecture of the mitral valve and the presence or absence of calcification, as well as pliability of the leaflets, are important factors in determining whether a patient with mitral stenosis is a candidate for commissurotomy. ${ }^{1213}$ Our findings indicate that a detailed morphological analysis of the mitral valve orifice is echocardiographically possible. An exact correspondence in shape was found in $85 \%$ of patients when correlating the data to the postoperative radiographic findings. Moreover, in $75 \%$ the exact localisation of the calcium deposits. was possible. In this regard two dimensional echocardiography in long and short axis planes seems to be superior to preoperative $x$-ray examination. With the latter method, leaflet calcification may be readily confused with annular calcium, which need not necessarily affect the mobility of the cusps. ${ }^{13}$

In rheumatic mitral valve disease the thickening and calcification of the valve tend to spread from the tips towards the base of the leaflets. ${ }^{14}$ The tomographic short axis cross-sections through the mitral valve orifice are therefore suitable for detecting early calcification. Abnormally intense and globular echoes of the leaflets and commissures were identified as calcium deposits. A similar echo pattern was described by Schwartz et al. ${ }^{15}$ doing in vitro studies with $M$-mode echocardiography in calcified and noncalcified valves.

With application of the grading system proposed by Lachman and Roberts ${ }^{8}$ the amount of calcium could be reliably determined by two dimensional echocardiography. These results confirm earlier studies, performed with the $M$-mode technique, which also semiquantified the calcification of mitral leaflets. ${ }^{16-18}$ But the exact quantification and localisation of echoes is sometimes difficult with the M-mode method. Multiple echoes generated by heavily calcified valves make it impossible to distinguish reliably echoes produced by the posterior cusp from those produced by the anterior leaflet.
Though not statistically significant some overestimation of the amount of calcium was obtained with two dimensional echocardiography. These false positive results can be accounted for by extensive fibrosis and thickening of cusps which produce a similar echo pattern. According to first reports by Rogers et al. ${ }^{19}$ the estimation and differentiation of tissue calcium can be further enhanced by digital processing of ultrasound signals. The application of this method to patients with atherosclerotic coronary arteries leads to an improvement of tissue characterisation in comparison with conventional techniques.

In conclusion, two dimensional echocardiography allows detailed morphological studies of stenotic mitral valves. The degree of mitral stenosis can be reliably determined by means of planimetry. Furthermore, an assessment of the shape of the valve orifice and of the degree and localisation of calcification is possible. These non-invasive data are of special importance for planning operative treatment.

\section{References}

1 Cope GD, Kisslo JA, Johnson ML, Behar VS. A reassessment of the echocardiogram in mitral stenosis. Circulation 1975; 52: 664-70.

2 Haerten K, Köhler E, Jaeschke M, Loogen F. Die Wertigkeit des Mitralklappenschließungsindex in der echokardiographischen Quantifizierung der Mitralstenose. Z Kardiol 1979; 68: 541-6.

3 Henry WL, Griffith JM, Michaelis LL, McIntosh CL, Morrow AG, Epstein SE. Measurement of mitral orifice area in patients with mitral valve disease by real-time two-dimensional echocardiography. Circulation 1975; 51: 827-31.

4 Nichol PM, Gilbert BW, Kisslo JA. Two-dimensional echocardiographic assessment of mitral stenosis. Circulation 1977; 55: 120-8.

5 Wann LS, Weyman AE, Feigenbaum H, Dillion JC, Johnston KW, Eggleton RC. Determination of mitral valve area by cross-sectional echocardiography. Ann Intern Med 1978; 88: 337-41.

6 Grube E, Steinborn W, Schulz U, Fehske W, Richter R, Simon H. Bestimmung des Schweregrades von Mitralstenosen mit Hilfe haemodynamischer und echokardiographischer Parameter. Z Kardiol 1978; 67: 637-44.

7 Anderson WA, Arnold JT, Clark D, et al. A new realtime phased array sector scanner for imaging the entire adult human heart. In: White $D$, Brown $R$, eds. Ultrasound in medicine. New York: Plenum, 1977: 1547-58.

8 Lachman AS, Roberts WC. Calcific deposits in stenotic mitral valves. Extent and relation to age, sex, degree of stenosis, cardiac rhythm, previous commissurotomy, and left atrial body thrombus from study of 164 operatively excised valves. Circulation 1978; 57: 808-15.

9 Gorlin R, Gorlin SG. Hydraulic formula for calculation of area of stenotic mitral valve, other cardiac valves and central circulatory shunts. Am Heart f 1951; 41: 1-29. 
10 Martin RP, Rakowski H, Kleiman JH, Beaver W, London E, Popp RL. Reliability and reproducibility of twodimensional echocardiographic measurement of the stenotic mitral valve orifice area. Am f Cardiol 1979; 43: 560-8.

11 Popp RL. Reliability of M-mode and cross-sectional echocardiographic criteria for the diagnosis of mitral valve disorders. In: Lance CT, ed. Echocardiology 1979. The Hague, Boston, and London: Nijhoff, 1979: 20312.

12 Oury JH, Peterson KL, Folkerth TL, Daily PO. Mitral valve replacement versus reconstruction. $\mathcal{f}$ Thorac Cardiovasc Surg 1977; 73: 825-35.

13 Michell G. Calcific mitral stenosis and mitral valvotomy. $\mathrm{Br}$ Med F 1960; i: 687-91.

14 Naito M, Morganroth J, Mardelli TJ, Chen CC, Dreifus LS. Rheumatic mitral stenosis: cross-sectional echocardiographic analysis. Am Heart f 1980; 100: 34-40.

15 Schwartz RG, Nanda NC, Gramiak R. Calcification and fibrosis of mitral valves: in vitro ultrasonic studies and clinical correlations. In: White D, Lyons EA, eds. Ultrasound in medicine. New York: Plenum, 1978: 55-6.
16 Nanda NC, Gramiak R, Shah PM, DeWeese JA. Mitral commissurotomy versus replacement. Preoperative evaluation by echocardiography. Circulation 1975; 51: 263-7.

17 Raj MVJ, Bennett DH, Stovin PGI, Evans DW. Echocardiographic assessment of mitral valve calcification. Br Heart f 1976; 38: 81-4.

18 Nicolosi GL, Pugh DM, Dunn M. Sensitivity and specificity of echocardiography in the assessment of valve calcification in mitral stenosis. Am Heart $\mathcal{f}$ 1979; 98: 171-5.

19 Rogers EW, Feigenbaum H, Weyman AE, Godley RW, Johnston KW, Eggleton RC. Possible detection of atherosclerotic coronary calcification by two-dimensional echocardiography. Circulation 1980; 62: 1046-53.

Requests for reprints to Dr Peter Schweizer, Department of Internal Medicine I, Rheinisch-Westfälische Technische Hochschule, Goethestrasse 27-29, D-5100 Aachen, West Germany. 